\title{
REVIEW
}

\section{Modeling of hydrological processes in arid agricultural regions}

\author{
Jiang LI ${ }^{1}$, Xiaomin MAO $(\bowtie){ }^{1}$, Shaozhong KANG ${ }^{1}$, David A. BARRY ${ }^{2}$ \\ 1 College of Water Resources and Civil Engineering, China Agricultural University, Beijing 100083, China \\ 2 Laboratoire de technologie écologique, Institut d'ingénierie de l'environnement, Station 2, \\ Ecole polytechnique fédérale de Lausanne (EPFL), CH-1015 Lausanne, Switzerland
}

\begin{abstract}
Understanding of hydrological processes, including consideration of interactions between vegetation growth and water transfer in the root zone, underpins efficient use of water resources in arid-zone agriculture. Water transfers take place in the soil-plant-atmosphere continuum, and include groundwater dynamics, unsaturated zone flow, evaporation/transpiration from vegetated/ bare soil and surface water, agricultural canal/surface water flow and seepage, and well pumping. Models can be categorized into three classes: (1) regional distributed hydrological models with various land uses, (2) groundwater-soil-plant-atmosphere continuum models that neglect lateral water fluxes, and (3) coupled models with groundwater flow and unsaturated zone water dynamics. This review highlights, in addition, future research challenges in modeling arid-zone agricultural systems, e.g., to effectively assimilate data from remote sensing, and to fully reflect climate change effects at various model scales.
\end{abstract}

Keywords hydrological processes, irrigation area, SPAC, crop growth, groundwater, canal seepage

\section{Introduction}

Arid regions (annual precipitation less than $200 \mathrm{~mm}^{[1]}$ ) are found in many parts of the world ${ }^{[2]}$. For instance, the arid north-west of China, which is an essential food production are ${ }^{[3]}$, totals about a third of the country ${ }^{[4]}$ and is home to 400 million residents ${ }^{[5]}$. As is well known, water shortages in arid areas lead to ecosystem degradation ${ }^{[6]}$. While

Received September 30, 2015; accepted November 13, 2015

Correspondence: maoxiaomin@cau.edu.cn agricultural yields improve with increased farmland and irrigation, overexploitation of groundwater resources leads to continuing depletion of groundwater levels ${ }^{[7]}$. More generally, diversion of water resources to agriculture negatively impacts on natural ecosystems ${ }^{[8]}$ and can lead to encroachment of peripheral deserts, for example.

Since local precipitation is usually insufficient to sustain agriculture, water resources in arid areas mainly come from upstream surface water and groundwater. This water is then diverted to or pumped onto farmland where it is transpired by crops, or enters surface water/groundwater by runoff, drainage or deep percolation. Obviously, water scarcity increases the need to quantify the main components of the water cycle so that allocations can be adopted that benefit in an efficient manner the agricultural economy while sustaining vulnerable ecological systems.

In situ monitoring of crop water consumption, groundwater levels and surface water flows provides essential data underpinning quantification of the dynamics of water transfers and partitioning into different uses. These tasks rely on comprehensive, integrated modeling of the water cycle and its interaction with vegetation, especially crop growth if agricultural regions are considered. Such models systematically provide a more complete view of sources and movement of water, and importantly explain the interactions between various water compartments and uses, thereby providing the basis for enhancement of water utilization efficiency.

Depending on the spatial domain considered, different approaches can be taken for saturated and unsaturated zones. If the focus is on groundwater flow (e.g., in a regional scale model) then fluxes between unsaturated and saturated zones can be represented as source/sink terms ${ }^{[9]}$. If water consumption and transfers due to different land uses are targeted then the groundwater phreatic surface elevation can be imposed as bottom boundary ${ }^{[10]}$. This is generally the case for SPAC (soil-plant-atmosphere 
continuum) ${ }^{[11]}$ or $\mathrm{SVAT}^{[12]}$ (soil-vegetation-atmospheretransfer) models. Modeling hydrological processes in both saturated and unsaturated zones in agricultural regions is challenging because it requires extensive spatial and temporal knowledge of different parameters. Additionally, it is computationally demanding for large saturatedunsaturated zones found in arid regions. Models of saturated and unsaturated zones are readily available, e.g., FEFLOW, which is capable of simulating 3D water flow in both unsaturated and saturated zones ${ }^{[13]}$. This model, however, neglects interactions between crop growth and water availability in the root zone and thus is unable to describe the influence of irrigation schedules on evapotranspiration, crop yield, and water flux under the root zone.

Many hydrological models developed recently consider runoff, evapotranspiration/plant growth, percolation, and groundwater flow, with either lumped (e.g., $\mathrm{TANK}^{[14]}$ ) or distributed (e.g., SWAT ${ }^{[15]}$ ) model parameters. Most are designed for non-arid regions with surface water runoff. Few consider the quite different circumstances found in arid areas, where surface water is distributed into farmland from rivers/canals instead of accumulated into rivers, and where water is mainly consumed through evapotranspiration.

Here, we review the main factors involved in hydrological processes in arid-zone agriculture, together with current hydrological models.

\section{Hydrological processes in arid agricultural regions}

Unlike humid areas where large quantities of surface runoff are produced by rainfall and converge into rivers, in arid areas (especially irrigation areas) water is diverted from canals/rivers to farmland, and consumed largely by evaporation/transpiration. Figure. 1 shows the main hydrological processes affecting arid regions as well as the various ground cover found there. In the vadose zone, water transfer is mainly in a vertical direction. Several different processes are involved in vertical water movement since it covers the SPAC ${ }^{[16]}$, including infiltration from irrigation or rainfall, deep percolation/upward flux from phreatic water, bare soil evaporation, and root uptake/ transpiration. For the groundwater zone, lateral movement cannot be neglected, along with its interactions with the vadose zone. In arid regions, vegetation growth/decay, especially of crops, must be considered as this is a major factor in water balance, showing the agricultural impact on hydrology process.

\subsection{Evapotranspiration}

Evapotranspiration $(E T)$, including evaporation $(E)$ from the soil/water surface and transpiration (Tr) from vegetation, is a key factor in energy transfer between the land surface and the atmosphere, as well as being the main means of water removal from arid areas. It influences vegetation growth and crop yield, and also removes water from the unsaturated zone and stimulates the upward water flow $^{[17-19]}$. ET has usually been monitored by weighing lysimeters, eddy covariance and Bowen ratio systems in situ $^{[20-22]}$. Because ET monitoring is expensive, timeconsuming and site specific, it can also be calculated by the Penman model (Eq. 1) ${ }^{[23]}$, Penman-Monteith (PM) model (Eq. 2) ${ }^{[24]}$, or reference ET methods such as FAO56 Penman-Monteith (FAO-PM) (Eqs. 3-4) ${ }^{[25]}$ :

$$
E=\frac{\Delta R_{n}+\gamma E_{a}}{\Delta+\gamma}
$$

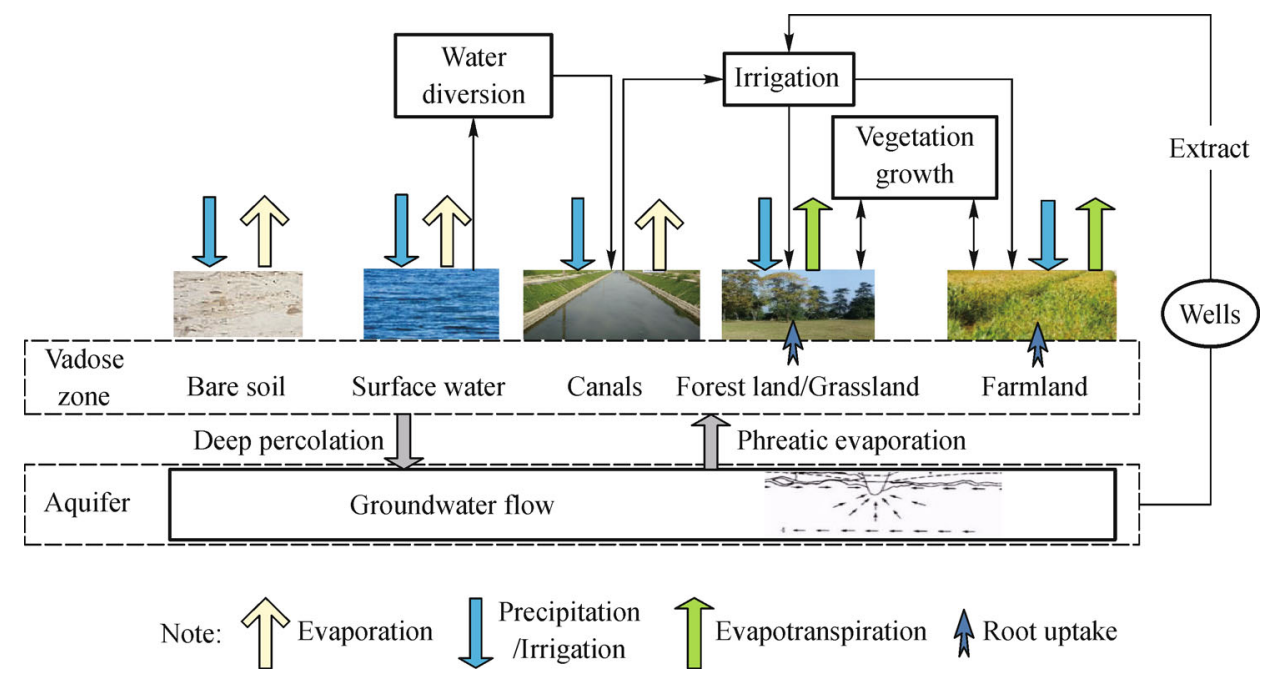

Fig. 1 Main hydrological processes in arid areas 


$$
\begin{gathered}
E T=\frac{1}{\lambda} \frac{\Delta\left(R_{n}-G\right)+\rho_{a} c_{p} \frac{\left(e_{s}-e_{a}\right)}{r_{a}}}{\Delta+\gamma\left(1+\frac{r_{s}}{r_{a}}\right)} \\
E T=K_{s} K_{c} E T_{0} \\
E T_{0}=\frac{0.408 \Delta\left(R_{n}-G\right)+\gamma \frac{900}{T+273} U\left(e_{s}-e_{a}\right)}{\Delta+\gamma(1+0.34 U)}
\end{gathered}
$$

where $R_{n}$ is net radiation, $\Delta$ is the slope of the saturation vapor pressure curve, $E_{a}$ is evaporation rate from open water obtained by putting saturation vapor pressure equal to actual vapor pressure in the sink strength formula, $\gamma$ is the hydrometric constant, $\lambda$ is latent heat of vaporization, $G$ is soil heat flux, $e_{s}$ is saturation vapor pressure for a given time period, $e_{a}$ is actual vapor pressure, $\rho_{a}$ is mean air density, $c_{p}$ is specific heat of air, $r_{s}$ is (bulk) surface or canopy resistance, $r_{a}$ is aerodynamic resistance, $K_{s}$ is soil water stress coefficient, $K_{c}$ is crop coefficient, $E T_{0}$ is reference crop evapotranspiration, $T$ is average daily temperature at $2 \mathrm{~m}$ above the ground surface and $U$ is wind speed at $2 \mathrm{~m}$ above the ground surface.

To partition $E T$ to $E$ and $T r$, many models were developed like the Shuttleworth-Wallace model ${ }^{[26]}$, the energy and water balance (ENWATBAL) model ${ }^{[27]}$, the Cupid-DPEVAP model ${ }^{[28]}$, and the FAO dual-Kc mode ${ }^{[25]}$. More advanced models for simulating water and heat transfer in SPAC ${ }^{[29]}$ or SVAT $^{[30]}$ can more accurately model ET under various canopy structures and water stresses in the root zone. Shang et al. ${ }^{[31]}$ simulated the response of evaporation and transpiration of winter wheat under various deficit irrigation treatment using a SPAC model ${ }^{[32]}$. Olioso et al. ${ }^{[33]}$ used two SVAT models to estimate evaporation and photosynthesis using remote sensing data.

For water management, a major challenge in $E T$ is how to calculate and predict long-term ET over large areas, accounting for land use types, crop growth dynamics, and heterogeneous soil water conditions. Remote sensing data are valuable for this, and is used frequently ${ }^{[34]}$. However, the spatial data resolution is insufficient to differentiate in detail the land surface, e.g., crop planting structure ${ }^{[35]}$, and temporally the sampling interval is generally large. Locally implemented SPAC models, on the other hand, account for specific land uses, and provide detailed time evolution of evaporation and transpiration in each specified area ${ }^{[36]}$. There have been some attempts to couple these two methods together, e.g., Yang et al. ${ }^{[37]}$ estimated spatial and temporal patterns of ET in the Hetao Irrigation District using the Surface Energy Balance Algorithm for Land (SEBAL) with MODIS data.
2.2 Percolation/phreatic evaporation-water exchange between saturated and unsaturated zones

Flood irrigation is a common practice in many arid agricultural regions. Although this method is not the most efficient means of water delivery, it helps prevent soil salinization in the crop root zone since addition of sufficient water induces deep percolation. Deep percolation rate can be estimated directly by the Darcian flux calculation method if estimates of in situ soil water potential profiles are available, e.g., by water balance or chloride mass balance modeling ${ }^{[38]}$. Empirical formulas relating to root zone water storage and to field capacity can also be used ${ }^{[39]}$. By considering the water table as the bottom boundary, numerical simulation of water transfer in the SPAC or groundwater-soil-plant-atmosphere continuum (GSPAC) can provide a more detailed prediction of water exchange between saturated and unsaturated zones, including deep percolation from the root $z o n e^{[31]}$. The challenges in quantification of irrigation infiltration includes different irrigation techniques used in the field, irrigation quota and frequency, heterogeneous soil texture and structure, as well as different crop types and their growth dynamics. To solve these problems, a coupled model is required, e.g., a vertical 1D model for saturatedunsaturated water transfer should be coupled with a crop and/or a regional scale model ${ }^{[40]}$.

Upward groundwater flux to the unsaturated zone is also called phreatic evaporation. It is a significant component of groundwater balance in arid areas, which is influenced by the groundwater depth, soil properties and climate conditions $^{[41]}$. Groundwater flux to the unsaturated zone is mostly significant under bare soils or natural vegetation with a shallow water table ${ }^{[42]}$. Empirical methods are commonly used to calculate phreatic evaporation from bare soil, such as the Aver'yanov phreatic evaporation equations (Eq. 5) ${ }^{[43]}$, which consider the relationship between surface water evaporation and phreatic level; the Tsinghua equation (Eq. 6) ${ }^{[44]}$, which is based on the above equation but also takes into account maximum phreatic evaporation depth; and the Inverse-Logistic formula (Eq. 7) ${ }^{[45]}$, which can more precisely depict the relationship between groundwater depth and the coefficient of phreatic evaporation using inverse logistic-type functions:

$$
\begin{gathered}
E_{g}=E_{0}\left(1-\frac{H}{H_{\max }}\right)^{n} \\
E_{g}=E_{\max }\left(1-e^{-\eta E_{0} / E_{\max }}\right) \\
E_{g}=E_{0}\left(\frac{K}{1+s e^{r H}}\right)
\end{gathered}
$$


where $E_{g}$ is phreatic evaporation, $E_{0}$ is surface water evaporation rate, $H$ is phreatic level, $H_{\max }$ is maximum phreatic level, $n, \eta, K, s$ and $r$ are empirical constants.

Calculating the groundwater flux to the unsaturated zone is difficult in vegetated land because of water uptake by plant roots, and even more difficult in farmland where deep percolation and upward flux coexist depending on the soil moisture condition. Mao et al. ${ }^{[46]}$ developed an empirical method for estimating phreatic evaporation from farmland by deducing the depth of the unsaturated zone to account for the root uptake effect. Luo et al. ${ }^{[4]}$ modified the Aver'yanov equation after introducing the concept of the crop influence coefficient to calculate groundwater flux to the unsaturated zone under crop growth conditions.

Numerical simulation is more commonly used to calculate groundwater flux. Torres and Hanks ${ }^{[48]}$ used the modified WATABLE model to simulate groundwater contribution to crop evapotranspiration under different groundwater depths and soil types. Mao et al. ${ }^{[49]}$ developed an evaporation model based on the energy balance at the soil surface, micrometeorology, moisture and heat transfer in unsaturated soil, which has been shown to be able to simulate groundwater recharge to the unsaturated zone under bare soil over long periods. Babajimopoulos et al. ${ }^{[50]}$ applied the mathematical model SWBACROS to estimate the shallow groundwater flux to the unsaturated zone. Meng et al. ${ }^{[51]}$ built a dynamic phreatic evaporation model for cropping periods that is helpful for irrigation scheduling. While most methods are for vertical 1D profiles, Luo et al. ${ }^{[52]}$ developed a GISbased model (GREGEC) for calculating regional groundwater evapotranspiration and applied it successfully to an irrigation district.

\subsection{River/canal seepage and well pumping}

River/canal seepage is a common physical phenomenon in arid areas, which is usually regarded as a loss of valuable water resources. Seepage has positive effects as well, because it recharges groundwater, keeping it at a reasonable level to sustain the growth of natural vegetation ${ }^{[53]}$. Pertinent quantification tools include analytical solutions and numerical simulations. Particularly for steady leakage, analytical formulas and predictions can be derived. For example, $\mathrm{He}^{[54]}$ gave approximate solutions to a fractional derivative model of seepage flow in porous media. Fox et al. ${ }^{[55]}$ proposed an analytical solution to estimate aquifer and stream bed leakage parameters by curve fitting of the field experimental data. Keery ${ }^{[56]}$ developed an analytical method for quantifying vertical water fluxes at the interface of groundwater-surface water. While analytical methods are usually easy to use and provide rapid answers, they often oversimplify real conditions. Alternatively, numerical simulations of combined saturated and unsaturated zone flows based on the Richards equation are readily available. For example, Yao et al. ${ }^{[57]}$ examined the canal seepage through a layered canal bed using HYDRUS-2D. Mao and Shang ${ }^{[58]}$ proposed the method of minimum flux in the saturation layer (MFSL), which can account for the impact of distinctly multilayered soil.

River/canal seepage and well pumping are the main sources and sinks of groundwater in arid areas. However, in irrigation districts, these terms are generally distributed in a complicated manner with many linear and point sources, making it difficult to incorporate them individually into a model. Current approaches normally regard them as areal sources that are distributed uniformly over areas of interest ${ }^{[59]}$. While appropriate for estimation of the regional water balance, this approach does not account for local hydrological differences. It is thus not appropriate for precision irrigation, and so loses the potential water use efficiency of the latter ${ }^{[60]}$. There is no conceptual difficulty in calculating spatially-distributed canal leakage and groundwater extraction by placing them on a digital map $^{[61]}$. However, there is still the challenge of determining line-type distributed canal seepage due to spatial variability of soil texture and structure under a canal bed, canal lining conditions, and seasonal variations in water levels. Depending on spatial area size, eventually the computational burden can become significant ${ }^{[61]}$.

\subsection{Crop growth/decay}

In irrigation districts, crop water use is a major part of the water balance, as mentioned above. Crop growth/decay involves root uptake, evapotranspiration, energy distribution and assimilation, i.e., it is at the intersection of hydrological and agricultural science.

Dynamic crop models incorporate crop growth/decay. There are three main types of models distinguished according to their key driving factors, i.e., carbon-driven models, radiation-driven models and water-driven models ${ }^{[62]}$. Carbon-driven models describe crop growth based on carbon assimilation, e.g., WOFOST ${ }^{[63]}$. Radiationdriven models drive crop biomass directly on intercepted solar radiation through a single conversion coefficient, radiation use efficiency ${ }^{[64]}$, e.g., the $\operatorname{EPIC}^{[65,66]}$ and CERES models ${ }^{[67]}$. For water-driven models, normally crop growth rate is linearly proportional to transpiration through a water productivity parameter ${ }^{[68]}$. It is the least complex model, needs correspondingly fewer input parameters ${ }^{[69,70]}$, and is particularly suitable for arid regions where water is the key limiting factor in crop production. There are two commonly-used water-driven models, CropSyst ${ }^{[71]}$ and AquaCrop ${ }^{[72]}$. Current crop models are normally point scale models, with some coupled to soil water and solute movement in vertical 1D profiles. 


\section{Current hydrological models in arid agricultural regions}

Current hydrological models used in arid-zone agriculture can be classified into three types, i.e., regional distributed hydrological models, areal GSPAC models that neglect lateral water fluxes and coupled models combining groundwater flow and unsaturated zone (or SPAC) water dynamics. Table 1 summarizes characteristics of several typical hydrological models. Generally, models with a detailed description of crop growth and its response to the local environment tend to focus on the local scale and neglect regional water interactions like lateral groundwater flow. Regional hydrological models account for surfacegroundwater interactions as well as lateral fluxes but tend to overlook water transfers in the unsaturated zone and fail to quantify interactions between vegetation and nearby soil water.

\subsection{Regional distributed hydrological models}

Regional distributed hydrological models originated from lumped conceptual models and developed quickly with the availability of distributed parameters through the $3 \mathrm{~S}$ technique (i.e., RS, GIS and GPS). Figure 2 shows the general concept of such a model. Conceptually, they originate from hydrological models used for flood forecasting ${ }^{[73]}$. Being based on hydrological water movement, they serve as tools for investigation of environmental pollution, water resources evaluation and for agricultural management. A widely used model is the Soil and Water Assessment Tool (SWAT), which is a distributed, continuous-time model that can be used to assess the impact of management on water supplies and nonpoint source pollution in watersheds and large river basins ${ }^{[73]}$. SWAT can simulate surface runoff, lateral flow in the soil profile, groundwater flow, evapotranspiration, canal routing and pond and reservoir storage. It includes several sub modules (e.g., pesticides, ponds/reservoirs, and lake water quality) with over parameterization or is usually connected to specific data sets with a restricted transferability. More versatility is given by SWIM (soil and water integrated model $)^{[74]}$, which couples SWAT with MATSALU ${ }^{[86]}$. SWIM includes a three-level spatial disaggregation scheme and some nitrogen modules from MATSALU, hydrological modules and the routing procedure from SWAT, with a modified GRASS interface. SWAT-based models use empirical equations to describe the lateral groundwater flow and are unable to describe combined irrigation and canal diversion. The WEP-L model ${ }^{[75]}$ was developed from the distributed hydrological model $\mathrm{WEP}^{[87]}$, and has improvements to its structure. WEP-L can simulate both the natural hydrological processes and water use with a water allocation and regulation model. The model contains many water use processes, including canal diversion, which are often neglected in regional distributed models.

The Tsinghua model ${ }^{[76]}$ was specifically developed for arid agricultural regions. It concentrates on water diversion from canals/rivers and subsequent removal from farmland by evapotranspiration. It includes different land/water regimes (river, spring-well, reservoir-lake, agriculture and non-agricultural areas) with hydraulic connections by surface canals and groundwater movement. The model was successfully applied to the oasis in the Akesu River Basin in north-west China ${ }^{[88]}$. Zhao et al. ${ }^{[7]}$ developed a similar model and applied it to the Hotan Oasis (DHMHO). They are both conceptual models without detailed descriptions of soil water dynamics in the saturatedunsaturated zone.

Table 1 Comparison of attributes of different hydrological models

\begin{tabular}{|c|c|c|c|c|c|c|c|c|c|c|}
\hline Model & Reference & Field application & $\mathrm{a}$ & $\mathrm{b}$ & $\mathrm{c}$ & d & $\mathrm{e}$ & $\mathrm{f}$ & $\mathrm{g}$ & $\mathrm{h}$ \\
\hline SWAT & [73] & Upper Trinity Basin & $\mathrm{Y}$ & 3 & $\mathrm{Y}$ & $\mathrm{N}$ & $\mathrm{Y}$ & $\mathrm{Y}$ & $\mathrm{N}$ & 1 \\
\hline SWIM & {$[74]$} & Elbe River Basin & $\mathrm{Y}$ & 3 & $\mathrm{Y}$ & $\mathrm{N}$ & $\mathrm{Y}$ & $\mathrm{Y}$ & $\mathrm{N}$ & 1 \\
\hline WEP-L & [75] & Yellow River Basin & $\mathrm{Y}$ & 2 & Y & $\mathrm{N}$ & $\mathrm{N}$ & Y & Y & 1 \\
\hline Tsinghua model & [76] & Akesu River Basin oasis & $\mathrm{Y}$ & 3 & $\mathrm{Y}$ & $\mathrm{N}$ & $\mathrm{N}$ & $\mathrm{N}$ & $\mathrm{Y}$ & 1 \\
\hline DHMHO & [77] & Hotan Oasis & $\mathrm{Y}$ & 3 & Y & $\mathrm{N}$ & $\mathrm{N}$ & $\mathrm{N}$ & Y & 1 \\
\hline GISAREG & [78] & Gafura-Gulyama & $\mathrm{Y}$ & 1 & $\mathrm{Y}$ & $\mathrm{N}$ & $\mathrm{Y}$ & $\mathrm{N}$ & $\mathrm{N}$ & 2 \\
\hline GSWAP & [79] & Hetao Irrigation District & $\mathrm{Y}$ & 1 & $\mathrm{Y}$ & $\mathrm{N}$ & Y & $\mathrm{N}$ & $\mathrm{N}$ & 2 \\
\hline AquaCrop + GIS & {$[80]$} & - & $\mathrm{Y}$ & 1 & $\mathrm{Y}$ & $\mathrm{N}$ & $\mathrm{Y}$ & $\mathrm{N}$ & $\mathrm{N}$ & 2 \\
\hline WOFOST + HYDRUS & [81] & Heihe River Basin & $\mathrm{Y}$ & 1 & $\mathrm{Y}$ & $\mathrm{Y}$ & Y & $\mathrm{N}$ & $\mathrm{N}$ & 2 \\
\hline HYDRUS + MODFLOW & [82] & Nete Catchment, Belgium & $\mathrm{Y}$ & 2 & $\mathrm{~N}$ & $\mathrm{~N}$ & $\mathrm{~N}$ & $\mathrm{~N}$ & $\mathrm{~N}$ & 3 \\
\hline SWATMOD & {$[83]$} & Rattlesnak Creek, Kansas & $\mathrm{Y}$ & 2 & $\mathrm{Y}$ & $\mathrm{N}$ & Y & Y & $\mathrm{N}$ & 3 \\
\hline SWAP + MODFLOW & [84] & Hetao Irrigaiton District & $\mathrm{Y}$ & 2 & Y & $\mathrm{N}$ & Y & $\mathrm{N}$ & $\mathrm{N}$ & 3 \\
\hline
\end{tabular}

Note: a, considers the ET with various ground cover, $\mathrm{Y}$ (yes)/ $\mathrm{N}$ (no); b, lateral groundwater fluxes: no consideration (1), considering groundwater movement by dynamic equation (2), and considering groundwater by empirical equation/water balance (3); c, considers the ET variation with crop types; d, considers the ET stomatal effect; e, simulates crop growth; f, considers surface runoff and accumulation; g, considers irrigation and canal diversion; h, model types: regional distributed hydrological model (1), areal GSPAC model neglecting lateral ground water flux (2), and coupled model with groundwater flow and unsaturated zone (or SPAC) water dynamics (3). 


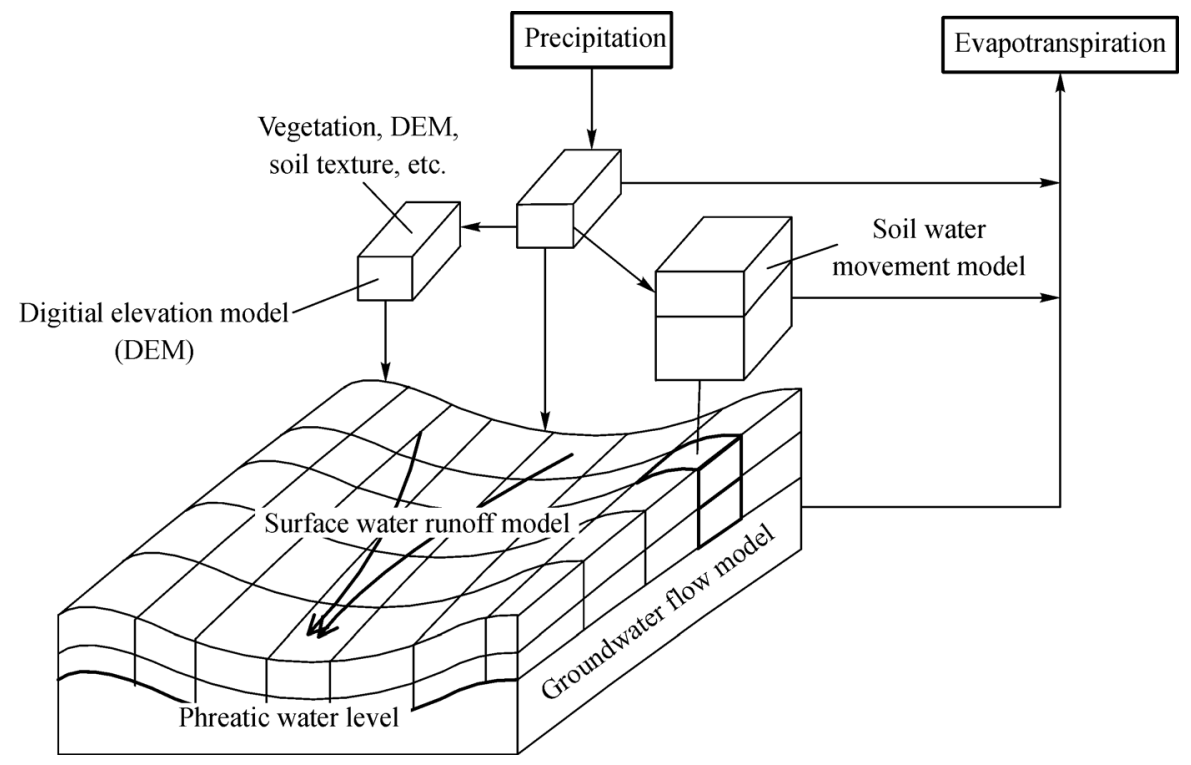

Fig. 2 Conceptual depiction of a regional distributed hydrological model (modified from Beven et al. ${ }^{[85]}$ )

3.2 Areal GSPAC models neglecting lateral ground water flux

Unlike the regional distributed hydrological models described above, GSPAC (groundwater-soil-plant-atmosphere continuum) models (Fig. 3) describe in detail the water/solute/heat transfer. Some models account also for crop growth, making them effective and commonly used tools for evaluation of water use efficiency in arid agricultural regions. Due to the problem of scale matching, most reported GSPAC model applications concentrate on water flow in unsaturated zones using the groundwater elevation as the bottom boundary, neglecting to account for lateral groundwater fluxes. This is despite the fact that groundwater flow is an important component for estimation of water, salt and energy balances in inland arid areas $^{[88]}$. Some areal GSPAC models couple an unsaturated zone model and a geographic information system (GIS). For example, ISAGEG ${ }^{[89]}$, which had been successfully used for various crops and under different environment, was integrated into GIS. The integrated model is called GISAREG ${ }^{[78]}$, which retains all features of ISAGEG and can be used to compute the spatial distributed crop water consumption. Some crop models have been coupled with GIS to describe regional soil water flow and crop growth. For instance, GSWAP ${ }^{[79]}-$ derived from the Soil-Water-Atmosphere-Plant (SWAP) mode ${ }^{[90]}$ and ArcInfo - can simulate soil water flow and salt transport on a regional scale. AquaCrop ${ }^{[72]}$ input and projects files are generated on a GIS platform. Two tools (AquaData and AquaGIS) manage the modeling task, which includes simulation of crop growth and the water balance in the unsaturated zone at regional scale ${ }^{[80]}$. Climate change, especially the rise of temperature and $\mathrm{CO}_{2}$ concentrations in the atmosphere, will certainly influence agricultural water consumption and crop yield ${ }^{[91]}$. However, neither SWAP nor AquaCrop considers the response of stomatal conductance to climate change since they use empirical equations to describe the relationship between stomatal conductance and photosynthesis/respiration. WOFOST $^{[63]}$ was developed from photosynthesis modeling based on plant biochemistry (photosynthesis and respiration), but the soil water dynamics modeling is relatively simple. This shortcoming is overcome by its coupling with HYDRUS ${ }^{[92]}$. WOFOST-HYDRUS connects soil water and plant dynamics quantitatively and is applicable to simulation of vadose zone moisture movement and crop growth ${ }^{[81]}$. The combined model has then been upscaled to the regional scale by integrating into a GIS $^{[93]}$.

\subsection{Coupled models of groundwater flow and unsaturated zone (or SPAC) water dynamics}

To consider the lateral groundwater flow and the vertical water transfer in the unsaturated zone simultaneously, a general technique is to develop coupled models with both groundwater flow and the unsaturated zone (or even SPAC water transfer with crop growth) water dynamics. Figure 4 shows an overview of such a coupled model. For instance, the unsaturated zone hydrological model HYDRUS-1D is fully coupled with the groundwater flow model MODFLOW $^{[94]}$. This combined model simulates groundwater flow and unsaturated zone water dynamics but does not consider directly effects of vegetation and meteorological factors $^{[82]}$. Given appropriate soil properties and other input data, the coupled model provides a sound basis to solve coupled vadose zone-groundwater flow problems, 

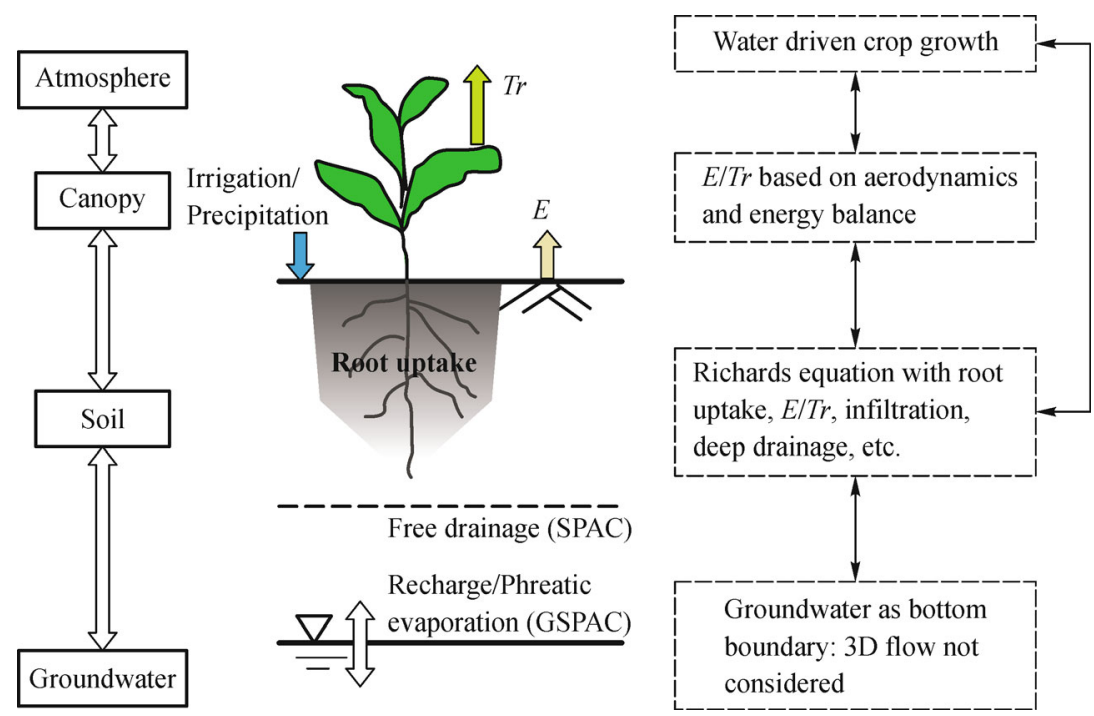

Fig. 3 Overview of the GSPAC model

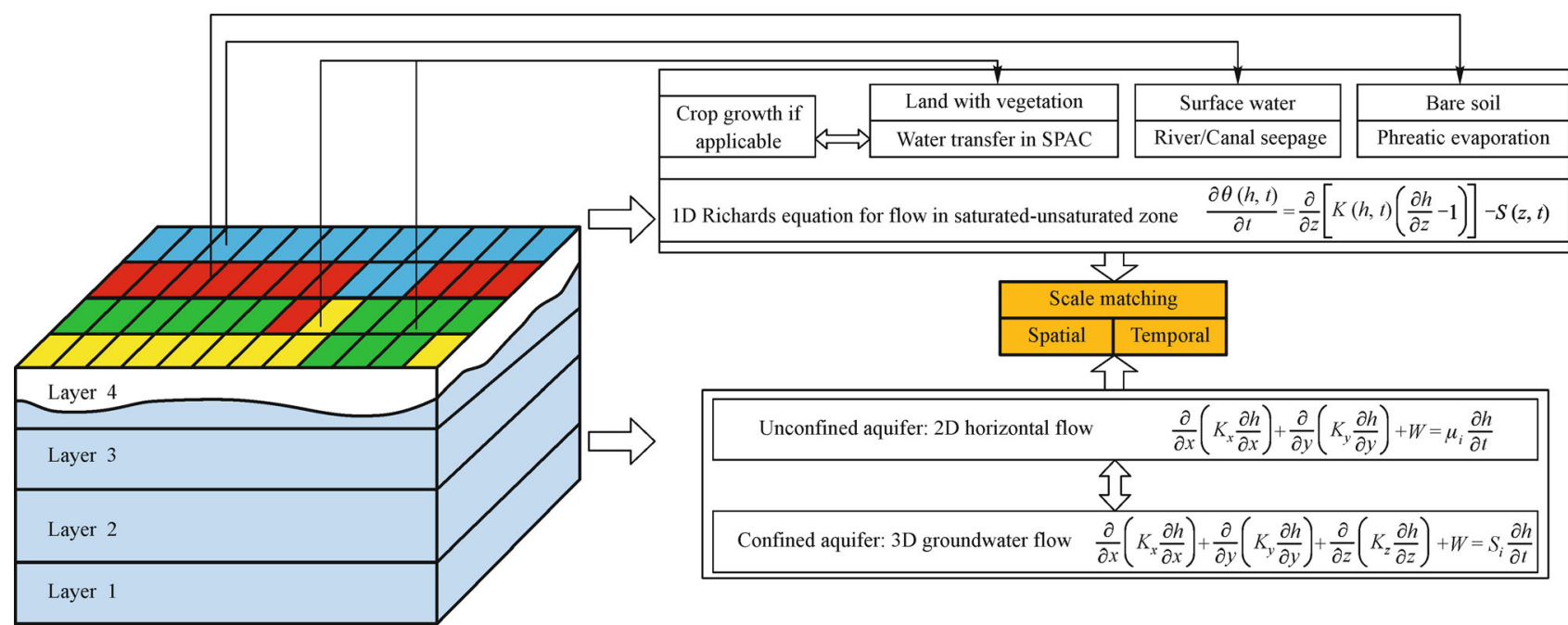

Fig. 4 Overview of a coupled vadose zone-groundwater flow model. $\theta$ is the volumetric soil water content; $h$ is the soil pressure head; $x$, $y, z$ are the coordinate symbols; $t$ is time; $K$ is the soil hydraulic conductivity; $S$ and $W$ are the source/sink terms; $K_{x}, K_{y}$ and $K_{z}$ are the hydraulic conductivity in directions $x, y$ and $z ; \mu_{s}$ is the specific yield and $S_{s}$ is the elastic drainable porosity.

even at regional scale (with sufficient computational resources). As stated above, SWAT is a distributed hydrological model with empirical equations to describe the lateral groundwater flow. Linking it with the MODFLOW groundwater model gives rise to SWATMOD ${ }^{[83]}$. The combined model simulates the flow of surface water, groundwater and stream-aquifer interactions on a continuous basis at regional scale. MODFLOW is also integrated to a simplified SWAP package through the exchange of water table depth and the net recharge, giving a coupled model that can simulate both water flow (e.g., 1D vertical flow in the vadose zone and 3D groundwater flow) and crop growth ${ }^{[84]}$.

\section{Challenges}

Remote sensing can be used directly to detect variation of 
surface water (e.g., lakes, wetlands), monitor melting of glaciers and snow, and even continuously monitor flood movement ${ }^{[95-98]}$. Also, it can be used indirectly to obtain the main parameters/terms in hydrological process, i.e., the land condition, the soil moisture, the regional evapotranspiration, the vegetation characteristics (e.g., LAI) and even crop yield ${ }^{[99-102]}$. Therefore, it is a valuable tool for provision of input and calibration data for hydrological models. With the development of remote sensing techniques, e.g., hyperspectral imaging ${ }^{[103]}$, current hydrological process modeling faces the challenge of incorporating effective data assimilation as well as improving simulation efficiency. Also, data in the vadose zone and the aquifer are still missing despite their large spatial heterogeneity. Invasive drilling is the traditional method for obtaining local data. However, geophysical methods can provide non-intrusive and more extensive data sets of the subsurface environment ${ }^{[104]}$. Therefore, it is necessary to assimilate large amounts of data while using limited directly measured validation data.

Climate change is a global concern. Its influence on regional precipitation and evaporation should be considered by hydrological models through downscaling the result of climate change models. The variation of local climate conditions, e.g., temperature and $\mathrm{CO}_{2}$ concentrations, can also influence the crop stomatal conductance and therefore influence the crop biomass accumulation, yield and agricultural water use efficiency. Although this small scale agricultural effect is closely related to large scale hydrological processes, modeling over disparate scales presents several challenges for parameter estimation and model coupling with external forcing factors. How to couple these effects into SPAC and how to further simulate socioeconomic effects in hydrological-agricultural models remains a challenge for hydrological process modeling in arid areas.

\section{Conclusions}

A detailed characterization of hydrological processes in arid areas is essential for efficient use of valuable agricultural water resources under harsh natural conditions. Here, we reviewed the methods for calculating the main terms in hydrological processes in arid-zone agriculture and models used for depicting them. Existing models are capable of giving a comprehensive understanding of hydrological process and can thus be used to help solve problems of local water resource management.

Note that due to data limitations, data assimilation and scale-matching problems, challenges still exist to effectively simulate the hydrological process in arid areas, such as inland river basins in China. Computational demands can also rapidly make direct application of detailed models impractical. It is especially challenging when considering the future climate change and human activity scenarios.
Current research programs, such as the key research plan from the National Natural Science Foundation of China, support research on these challenges, for instance, integrative research on eco-hydrological processes in the Heihe River Basin. This support underpins field experiments, data monitoring, collecting and assimilation, as well as model calibration, validation and application. Through this and the other similar projects, progress in hydrological modeling of agriculturally important arid areas is expected.

Acknowledgements This study was funded by the National Natural Science Foundation of China $(91425302,91125017,51321001)$ and the Program of Introducing Talents of Discipline to Universities (B14002).

Compliance with ethics guidelines Jiang Li, Xiaomin Mao, Shaozhong Kang, and David A. Barry declare that they have no conflict of interest or financial conflicts to disclose.

This article is a review and does not contain any studies with human or animal subjects performed by any of the authors.

\section{References}

1. Thomas D S G. Arid zone geomorphology - Process, form and change in dryland. 2nd ed. Hoboken: John Wiley \& Sons, 2011

2. Qian Z A, Song M H, Li W Y, Cai Y. Global, China-Mongolia Arid-and Semiarid-Areas (CMASA) and the details of precipitation distribution in part regions of CMASA. Plateau Meteorology, 2011, 30(1): 1-30 (in Chinese)

3. Gu L L. Research on evolution and development of major grainproducing areas in China. Dissertation for the Doctoral Degree. Jilin: Jilin Agricultural University, 2012 (in Chinese)

4. Wang G X, Cheng G D, Xu Z M. The utilization of water resource and its influence on eco-environment in the northwest arid area of China. Journal of Natural Resources, 1999, 14(2): 109-116 (in Chinese)

5. Zhang H. Spatial-temporal variations of population and population distribution with data at county level in Northwest China in 19902010. Journal of Arid Land Resources and Environment, 2013, 27 (7): 33-39 (in Chinese)

6. Postel S L, Daily G C, Ehrlich P R. Human appropriation of renewable fresh water. Science, 1996, 271(5250): 785-787

7. Liu C M, Yu J J, Kendy E. Groundwater exploitation and its impact on the environment in the North China Plain. Water International, 2001, 26(2): 265-272

8. Wei L L. The research of water resource sustainable utilization in Manas River Basin. Dissertation for the Doctoral Degree. Shihezi: Shihezi University, 2014 (in Chinese)

9. Xu X, Huang G H, Qu Z Y, Pereira L S. Using MODFLOW and GIS to assess changes in groundwater dynamics in response to water saving measures in irrigation districts of the upper Yellow River Basin. Water Resources Management, 2011, 25(8): 20352059

10. Fu B J, Zhao W W, Chen L D, Liu Z F, Lu Y H. Eco-hydrological effects of landscape pattern change. Landscape and Ecological Engineering, 2005, 1(1): 25-32 
11. Song G H. Study on groundwater dependent ecosystem and ecological mechanisms of vegetation succession in desert lakebasin region. Dissertation for the Doctoral Degree. Xi'an: Chang'an University, 2012 (in Chinese)

12. Wei S P, Wang L, Wu F Q. Research and application of SVAT models. Science of Soil and Water Conservation, 2008, 6(2): 113120 (in Chinese)

13. Huo Z L, Feng S Y, Kang S Z, Cen S J, Ma Y. Simulation of effects of agricultural activities on groundwater level by combining FEFLOW and GIS. New Zealand Journal of Agricultural Research, 2007, 50(5): 839-846

14. Sugawara M. The development of a hydrological model- tank. In: Kite G W, ed., Time and the River, Essays by Eminent Hydrologists. Colorado: Water Resources Publications, 1995, 201-258

15. Arnold J G, Fohrer N. SWAT2000: current capabilities and research opportunities in applied watershed modelling. Hydrological Processes, 2005, 19(3): 563-572

16. Shao M A, Chen Z M. Water movement in SPAC. Research of Soil and Water Conservation, 1991, 1: 3-12 (in Chinese)

17. Zhao W Z, Cheng G D. Review of several problems on the study of eco-hydrological processes in arid zones. Chinese Science Bulletin, 2002, 47(5): 353-360

18. Huang $\mathrm{J}$ T. The response of evapotranspiration to the groundwater changes in the semi-arid area. Dissertation for the Doctoral Degree. Xi'an: Chang'an University, 2013 (in Chinese)

19. Ladekarl U L, Rasmussen K R, Christensen S, Jensen K H, Hansen B. Groundwater recharge and evapotranspiration for two natural ecosystems covered with oak and heather. Journal of Hydrology, 2005, 300(1-4): 76-99

20. Wegehenkel M, Gerke H H. Comparison of real evapotranspiration measured by weighing lysimeters with simulations based on the Penman formula and a crop growth model. Journal of Hydrology and Hydromechanics, 2013, 61(2): 161-172

21. Liu S M, Xu Z W, Zhu Z L, Jia Z Z, Zhu M J. Measurements of evapotranspiration from eddy-covariance systems and large aperture scintillometers in the Hai River Basin, China. Journal of Hydrology, 2013, 487: 24-38

22. Holland S, Heitman J L, Howard A, Sauer T J, Giese W, BenGal A, Agam N, Kool D, Havlin J. Micro-Bowen ratio system for measuring evapotranspiration in a vineyard interrow. Agricultural and Forest Meteorology, 2013, 177: 93-100

23. Penman H L. Natural evaporation from open water, bare soil and grass. Proceedings of the Royal Society of London. Series A, Mathematical and Physical Sciences, 1948, 193(1032): 120-145

24. Monteith J L. Evaporation and environment. Proceedings of the Society for Experimental Biology and Medicine, 1965, 19: 205234

25. Allen R G, Pereira L S, Raes D, Smith M. Crop evapotranspirationGuidelines for computing crop water requirements- FAO Irrigation and drainage paper 56. Rome: FAO, 1998

26. Shuttleworth W J, Wallace J S. Evaporation from sparse crops-an energy combination theory. Quarterly Journal of the Royal Meteorological Society, 1985, 111(469): 839-855

27. Lascano R J, van Bavel C H M, Hatfield J L, Upchurch D R.
Energy and Water Balance of a Sparse Crop: Simulated and Measured Soil and Crop Evaporation. Soil Science Society of America Journal, 1987, 51(5): 1113-1121

28. Thompson A L, Gilley J R, Norman J M. A sprinkler water droplet evaporation and plant canopy model. I. Model development. Transactions of the ASAE, 1993, 36(3): 735-741

29. Federr C A. A soil-plant-atmosphere model for transpiration and availability of soil water. Water Resources Research, 1979, 15(3): 555-562

30. Franks S W, Beven K J, Quinn P F, Wright I R. On the sensitivity of soil-vegetation-atmosphere transfer (SVAT) schemes: equifinality and the problem of robust calibration. Agricultural and Forest Meteorology, 1997, 86(1): 63-75

31. Shang S H, Mao X M, Lei Z D, Yang S X. Simulation model of soil water dynamics and its application. Beijing: Science Press, 2009 (in Chinese)

32. Mao X M. A study of water and heat transfer in groundwater-soilplant-atmosphere system in the oasis of arid area. Dissertation for the Doctoral Degree. Beijing: Tsinghua University, 1998 (in Chinese)

33. Olioso A, Chauki H, Courault D, Wigneron J P. Estimation of evapotranspiration and photosynthesis by assimilation of remote sensing data into SVAT models. Remote Sensing of Environment, 1999, 68(3): 341-356

34. Cristiano P M, Campanello P I, Bucci S J, Rodriguez S A, Lezcano O A, Scholz F G, Madanes N, Di Francescantonio D, Carrasco L O, Zhang Y J, Goldstein G. Evapotranspiration of subtropical forests and tree plantations: a comparative analysis at different temporal and spatial scales. Agricultural and Forest Meteorology, 2015, 203: 96-106

35. Wu X J, Zhou J, Wang H J, Li Y, Zhou B. Evaluation of irrigation water use efficiency using remote sensing in the middle reach of the Heihe River, in the semi-arid Northwestern China. Hydrological Processes, 2015, 29(9): 2243-2257

36. Consoli S, Vanella D. Mapping crop evapotranspiration by integrating vegetation indices into a soil water balance model. Agricultural Water Management, 2014, 143: 71-81

37. Yang Y T, Shang S H, Jiang L. Remote sensing temporal and spatial patterns of evapotranspiration and the responses to water management in a large irrigation district of North China. Agricultural and Forest Meteorology, 2012, 164: 112-122

38. Willis T M, Black A S, Meyer W S. Estimates of deep percolation beneath cotton in the Macquarie Valley. Irrigation Science, 1997, 17(4): 141-150

39. Liu Y, Pereira L S, Fernando R M. Fluxes through the bottom boundary of the root zone in silty soils: parametric approaches to estimate groundwater contribution and percolation. Agricultural Water Management, 2006, 84(1-2): 27-40

40. Burrows W, Doherty J. Efficient calibration/uncertainty analysis using paired complex/surrogate models. Ground Water, 2015, 53 (4): 531-541

41. Zhang Z H, Shi W J, Chu G H. Influence factor and calculation method of phreatic evaporation in arid region. Journal of Water Resources and Water Engineering, 2008, 19(6): 78-80 (in Chinese) 
42. Bian W Y. The simulation and analysis on evaporation-dynamic of groundwater in arid zone riverside. Dissertation for the Master Degree. Beijing: China University of Geosciences, 2011 (in Chinese)

43. Lei Z D, Yang S X, Xie S C. Soil hydrodynamics. Beijing: Tsinghua University Press, 1988 (in Chinese)

44. Lei Z D, Yang S X, Xie S C. Analysis and the empirical formula of steady phreatic evaporation. Journal of Hydraulic Engineering, 1984, 8: 60-64 (in Chinese)

45. Shang S H, Mao X M, Lei Z D, Zhou K, Zhong Y G, Aniwaer. Inverse-Logistic Formula for calculation of phreatic evaporation coefficient. Irrigation and Drainage, 1999, 18(2): 18-21 (in Chinese)

46. Mao X M, Lei Z D, Shang S H, Yang S X. Method of equivalent phreatic evaporation by lowering evaporation surface for estimation of the phreatic evaporation from farm land based on that from bare soil. Irrigation and Drainage, 1999, 18(2): 26-29 (in Chinese)

47. Luo Y F, Mao Y L, Peng S Z, Zheng Q, Wang W G, Jiao X Y, Feng Y H. Modified Aver'yanov's phreatic evaporation equations under crop growing. Transactions of CSAE, 2013, 29(4): 102-109 (in Chinese)

48. Torres J S, Hanks R J. Modeling water table contribution to crop evapotranspiration. Irrigation Science, 1989, 10(4): 265-279

49. Mao X M, Yang S X, Lei Z D. Numerical simulation of ground water evaporation from bare soil in Yerqiang River Basin. Advances in Water Science, 1997, 8(4): 313-320 (in Chinese)

50. Babajimopoulos C, Panoras A, Georgoussis H, Arampatzis G, Hatzigiannakis E, Papamichail D. Contribution to irrigation from shallow water table under field conditions. Agricultural Water Management, 2007, 92(3): 205-210

51. Meng W C, Meng C, Liu L. The study on phreatic evaporation model under different groundwater level, climatic factor and crop growing. Journal of Taiyuan University of Technology, 2008, 39 (4): 422-425 (in Chinese)

52. Luo Y F, Zheng Q, Peng S Z, Mao Y L. Calculating regional groundwater evapotranspiration based on GIS. Journal of Hydraulic Engineering, 2014, 45(1): 79-86 (in Chinese)

53. Yang P N, Wu B F, Wang S X, Dong X G, Liu L. Research on irrigation schedule of cotton drip irrigation under plastic film based on the different ground water table in arid areas. Agricultural Research in the Arid Areas, 2014, 32(3): 76-82 (in Chinese)

54. He J H. Approximate analytical solution for seepage flow with fractional derivatives in porous media. Computer Methods in Applied Mechanics and Engineering, 1998, 167(1): 57-68

55. Fox G A, DuChateau P, Dumford D S. Analytical model for aquifer response incorporating distributed stream leakage. Ground Water, 2002, 40(4): 378-384

56. Keery J, Binley A, Crook N, Smith J W N. Temporal and spatial variability of groundwater-surface water fluxes: development and application of an analytical method using temperature time series. Journal of Hydrology, 2007, 336(1): 1-16

57. Yao L Q, Feng S Y, Mao X M, Huo Z L, Kang S Z, Barry D A. Coupled effects of canal lining and multi-layered soil structure on canal seepage and soil water dynamics. Journal of Hydrology,
2012, 430-431: 91-102

58. Mao X M, Shang S H. Method of minimum flux in saturation layer for calculating stable infiltration through layered soil. Journal of Hydraulic Engineering, 2010, 41(7): 810-817 (in Chinese)

59. Feng S Y, Huo Z L, Kang S Z, Tang Z J, Wang F X. Groundwater simulation using a numerical model under different water resources management scenarios in an arid region of China. Environmental Earth Sciences, 2011, 62(5): 961-971

60. Pan Y H, Kang S Z. Irrigation water infiltration in furrows and crop water use of alternative furrow irrigation. Transactions of the CSAE, 2000, 16(1): 39-43 (in Chinese)

61. Sun Y. Analysis of temporal and spatial variations of groundwater environment and its numerical simulation in Shiyang River Basin. Dissertation for the Doctoral Degree. Beijing: China Agricultural University, 2010 (in Chinese)

62. Abedinpour M, Sarangi A, Rajput T B S, Singh M, Pathak H, Ahmad T. Performance evaluation of AquaCrop model for maize crop in a semi-arid environment. Agricultural Water Management, 2012, 110: 55-66

63. van Diepen C A, Wofl J, van Keulen H, Rappoldt C. WOFOST: a simulation model of crop production. Soil Use and Management, 1989, 5(1): 16-24

64. Monteith J L, Moss C J. Climate and the efficiency of crop production in Britain [and discussion]. Philosophical Transactions of the Royal Society of London B Biological Sciences, 1977, 281 (980): 277-294

65. Jones C A, Dyke P T, Williams J R, Kiniry J R, Benson V W, Griggs R H. EPIC: an operational model for evaluation of agricultural sustainability. Agricultural Systems, 1991, 37(4): 341350

66. Cabelguenne M, Debaeke P, Bouniols A. EPICphase, a version of the EPIC model simulating the effects of water and nitrogen stress on biomass and yield, taking account of developmental stages: validation on maize, sunflower, sorghum, soybean and winter wheat. Agricultural Systems, 1999, 60(3): 175-196

67. Ritchie J T, Otter S. Description and performance of CERESWheat: a user-oriented wheat yield model. Preliminary documentation. Agristars Publication, 1985, 159-175

68. Steduto P, Albrizio R. Resource use efficiency of field-grown sunflower, sorghum, wheat and chickpea. Agricultural and Forest Meteorology, 2005, 130(3-4): 269-281

69. Steduto P, Hsiao T C, Fereres E. On the conservative behavior of biomass water productivity. Irrigation Science, 2007, 25(3): 189207

70. Steduto P, Hsiao T C, Raes D, Fereres E. AquaCrop-The FAO Crop Model to Simulate Yield Response to Water: I. Concepts and Underlying Principles. Agronomy Journal, 2009, 101(3): 426437

71. St Ckle C O, Donatelli M, Nelson R. CropSyst, a cropping systems simulation model. European Journal of Agronomy, 2003, 18(3): 289-307

72. Steduto P, Hsiao T C, Raes D, Fereres E. AquaCrop -the FAO crop model to simulate yield response to water concepts and underlying principles. Agronomy Journal, 2009, 101(3): 426-437

73. Arnold J G, Srinivasan R, Muttiah R S, Williams J R. Large area 
hydrologic modeling and assessment part I: model development. Journal of the American Water Resources Association, 1998, 34 (1): 73-89

74. Krysanova V, Muller-Wohlfei D, Becker A. Development and test of a spatially distributed hydrological/water quality model for mesoscale watersheds. Ecological Modelling, 1998, 106(2): 261289

75. Jia Y W, Wang H, Zhou Z H, Qiu Y Q, Luo X Y, Wang J H, Yan D H, Qin D Y. Development of the WEP-L distributed hydrological model and dynamic assessment of water resources in the Yellow River basin. Journal of Hydrology, 2006, 331(3-4): 606-629

76. Hu H P, Tang Q H, Lei Z D, Yang S X. Runoff-evaporation hydrological model for arid plain oasis, 1, the model structure. Advance in Water Science, 2004, 15(2): 140-145 (in Chinese)

77. Zhao C S, Huang L M, Shen B, Lei Z D, Hu H P, Yang S X. The creation of the dissipative hydrological model for Hotan Oasis (DHMHO). Journal of Arid Land Resources and Environment, 2010, 24(7): 72-77 (in Chinese)

78. Fortes P S, Platonov A E, Pereira L S. GISAREG-A GIS based irrigation scheduling simulation model to support improved water use. Agricultural Water Management, 2005, 77(1-3): 159-179

79. Xu X, Huang G H, Qu Z Y, Huang Q Z. Regional scale model for simulating soil water flow and solute transport processes-GSWAP. Transactions of CSAE, 2011, 27(7): 58-63 (in Chinese)

80. Lorite I J, Garcua-Vila M, Santos C, Ruiz-Ramos M, Fereres E. AquaData and AquaGIS: Two computer utilities for temporal and spatial simulations of water-limited yield with AquaCrop. Computers and Electronics in Agriculture, 2013, 96: 227-237

81. Zhou J, Cheng G D, Hu B X, Wang G X. Numerical Modeling of Wheat Irrigation using Coupled HYDRUS and WOFOST Models. Soil Science Society of America Journal, 2012, 76(2): 648-662

82. Twarakavi N K C, Šimůnek J, Seo S. Evaluating interactions between groundwater and vadose zone using the HYDRUS-based flow package for MODFLOW. Vadose Zone Journal, 2008, 7(2): 757-768

83. Sophocleous M A, Koelliker J K, Govindaraju R S, Birdie T, Ramireddygari S R, Perkins S P. Integrated numerical modeling for basin-wide water management: The case of the Rattlesnake Creek basin in south-central Kansas. Journal of Hydrology, 1999, 214(1): 179-196

84. Xu X, Huang G H, Zhan H B, Qu Z Y, Huang Q Z. Integration of SWAP and MODFLOW-2000 for modeling groundwater dynamics in shallow water table areas. Journal of Hydrology, 2012, 412-413: 170-181

85. Beven K, Warren R, Zaoui J. SHE: towards a methodology for physically - based distributed forecasting in hydrology. Hydrological Forecasting, 1980, 129: 133-137

86. Krysanova V, Meiner A, Roosaare J, Vasilyev A. Simulation modelling of the coastal waters pollution from agricultural watershed. Ecological Modelling, 1989, 49(1): 7-29

87. Jia Y W, Ni G H, Kawahara Y, Suetsugi T. Development of WEP model and its application to an urban watershed. Hydrological Processes, 2001, 15(11): 2175-2194

88. Tang Q H, Tian F Q, Hu H P. Runoff-evaporation hydrological model for arid plain oasis, 2, applications of the model. Advance in
Water Science, 2004, 15(2): 146-150 (in Chinese)

89. Teixeira J L, Pereira L S. ISAREG, an irrigation scheduling model. ICID Bulletin, 1992, 41(2): 29-48

90. van Dam J C, Huygen J, Wesseling J G, Feddes R A, Kabat P, van Walsum P E V, Groenendijk P, van Diepen C A. Theory of SWAP Version 2.0: Simulation of Water Flow, Solute Transport and Plant Growth in the Soil-Water-Atmosphere-Plant Environment. Wageningen : Winand Staring Centre, 1997

91. Wu D X, Wang G X, Bai Y F, Liao J X. Effects of elevated $\mathrm{CO}_{2}$ concentration on growth, water use, yield and grain quality of wheat under tow soil water levels. Agriculture, Ecosystems \& Environment, 2004, 104(3): 493-507

92. Šimůnek J, Šejna M, Saito H, Sakai M, van Genuchten M T. The HYDRUS-1D software package for simulating the movement of water, heat, and multiple solutes in variably saturated media, version 4.0, HYDRUS software series 3. Riverside: University of California Riverside, California, USA. 2008

93. Li Y. Study on maize yield estimation using remote sensing technology integrated with coupled WOFOST and HYDRUS models. Dissertation for the Doctoral Degree. Lanzhou: Lanzhou University, 2012 (in Chinese)

94. Harbaugh A W, Banta E R, Hill M C, McDonald M G. MODFLOW-2000, the US Geological Survey modular groundwater model - user guide to modularization concepts and the groundwater flow process. Reston: US Geological Survey, 2000

95. Aandreadis K M, Lettenmaier D P. Assimilating remotely sensed snow observations into a macroscale hydrology model. Advances in Water Resources, 2006, 29(6): 872-886

96. Huang L, Li Z, Tian B S, Chen Q, Liu J L, Zhang R. Classification and snow line detection for glacial areas using the polarimetric SAR image. Remote Sensing of Environment, 2011, 115(7): 17211732

97. Crossman J, Bradley C, David J N W, Milner A M. Use of remote sensing to identify areas of groundwater upwelling on active glacial floodplains: The frequency, extent and significance on a landscape scale. Remote Sensing of Environment, 2012, 123: 116126

98. Huang L, Li Z, Tian B S, Chen Q, Zhou J M. Monitoring glacier zones and snow/firn line changes in the Qinghai-Tibetan Plateau Cband SAR imagery. Remote Sensing of Environment, 2013, 137: $17-30$

99. Kalma J D, McVicar T R, McCabe M F. Estimating land surface evaporation: A review of methods using remotely sensed surface temperature data. Surveys in Geophysics, 2008, 29(4-5): 421-469

100. Yebra M, van Dijk A, Leuning R, Huete A, Guereschman J P. Evaluation of optical remote sensing to estimate actual evapotranspiration and canopy conductance. Remote Sensing of Environment, 2013, 129: 250-261

101. Mo X, Liu S, Lin Z, Xu Y, Xiang Y, McVicar T R. Prediction of crop yield, water consumption and water use efficiency with a SVAT-crop growth model using remotely sensed data on the North China Plain. Ecological Modelling, 2005, 183(2-3): 301-322

102. Claverie M, Demarez V, Duchemin B, Hagolle O, Ducrot D, Marais-Sicre C, Dejoux J F, Huc M, Keravec P, Béziat P, Fieuzal R, Ceschia E, Dedieu G. Maize and sunflower biomass estimation 
in southwest France using high spatial and temporal resolution remote sensing data. Remote Sensing of Environment, 2012, 124: 844-857

103. Olioso A, Inoue Y, Ortega-FARIAS S, Demarty J, Wigneron J P, Braud I, Jacob F, Lecharpentier P, OttlÉ C, Calvet J C, Brisson N. lnoue Y. Future directions for advanced evapotranspiration modeling: Assimilation of remote sensing data into crop simulation models and SVAT models. Irrigation and Drainage Systems, 2005,
19(3-4): 377-412

104. Binley A, Hubbard S, Huisman J, Revil A, Robinson D, Singha K, Slater L. The emergence of hydrogeophysics for improved understanding of subsurface processes over multiple scales. Water Resources Research, 2015, 51(6): 1-30

105. Zhou A G, Ma R, Zhang C. Vertical water cycle and its ecological effect in inland basins, Northwest China. Advances in Water Science, 2005, 16(1): 127-133 (in Chinese) 